\section{Differential Photosynthetic Responses to Salinity Stress between Two Perennial Grass Species Contrasting in Salinity Tolerance}

\author{
Yiming Liu, Hongmei Du, and Kai Wang \\ School of Agricultural and Biological Sciences, Shanghai Jiao Tong \\ University, 800 DongChuan Road, MinHang District, Shanghai, 200240, \\ P.R. China
}

\author{
Bingru Huang \\ Department of Plant Biology and Pathology, Rutgers University, New Brunswick, \\ NJ 08901
}

\author{
Zhaolong Wang ${ }^{1}$ \\ School of Agricultural and Biological Sciences, Shanghai Jiao Tong \\ University, 800 DongChuan Road, MinHang District, Shanghai, 200240, \\ P.R. China
}

Additional index words. salt tolerance, warm-season turfgrass, physiology, phytosynthesis

\begin{abstract}
Salinity is a detrimental abiotic stress for plant growth in salt-affected soils. The objective of this study was to examine photosynthetic responses to salinity stress in two warm-season turfgrasses differing in salinity tolerance. Salt-tolerant species seashore paspalum (Paspalum vaginatum) and salt-sensitive species centipedegrass (Eremochloa ophiuroides) were exposed to salinity at three $\mathrm{NaCl}$ concentrations $(0,300$, and $500 \mathrm{~mm})$ in a growth chamber. Turf quality, relative water content (RWC), and leaf photochemical efficiency $(\mathrm{Fv} / \mathrm{Fm})$ declined, whereas electrolyte leakage $(\mathrm{EL})$ increased under the two $\mathrm{NaCl}$ regimes for both grass species, and the changes were more dramatic in centipedegrass than that in seashore paspalum as well as in the higher salinity concentration. Two grass species showed different phytosynthetic responses to salinity stress. The earlier inhibition of photosynthesis in seashore paspalum was mainly associated with stomatal closure. As salinity increased and salinity stress prolonged, the inhibition of photosynthesis in seashore paspalum was mainly associated with non-stomatal factors. The inhibition of photosynthesis in centipedegrass was associated with both stomatal closure and non-stomatal factors at both salinity levels. The sodium dodecyl sulfatepolyacrylamide gel electrophoresis (SDS-PAGE) analysis demonstrated the Rubisco large subunit had no obvious decrease during the whole stress period under the $300-\mathrm{mm}$ and 500-mm treatments in seashore paspalum, whereas it significantly decreased in centipedegrass under both the 300-mm and 500-mm treatments. The results indicated that the superior salinity tolerance in seashore paspalum, compared with centipedegrass, could be attributed to its maintenance of Rubisco stability, chlorophyll content, photochemical efficiency as well as photosynthetic rate (Pn) capacity under salinity stress.
\end{abstract}

Salinity is one of the major abiotic factors limiting plant growth in many areas of the world, which is progressively increasing as a result of the decline in fresh water for irrigation and increasing use of effluents that

Received for publication 1 Oct. 2010. Accepted for publication 3 Dec. 2010.

We thank Hongmei Du, Peng Zhou, and Longxing $\mathrm{Hu}$ at Shanghai Jiaotong University for reviewing this manuscript. We especially thank the Chinese Ministry of Education for awarding the Chang Jiang Fellowship grant to Dr. Bingru Huang, who provided valuable comments on an earlier version of the manuscript.

${ }^{1}$ To whom reprint requests should be addressed; e-mail turf@sjtu.edu.cn. contain concentrations of salts that damage agricultural and landscape plants when they are used for irrigation (Carrow and Duncan, 1998; Munns and Tester, 2008). Salinity may cause damage in plants through its effects on various physiological processes, including induction of water deficit, ion toxicity, and nutrient deficiency, leading to cellular damage and growth reduction and even plant death (Munns, 2005; Sahar et al., 2007; Tester and Davenport, 2003). In several turfgrass species such as kentucky bluegrass (Poa pratensis), tall fescue (Festuca arundinacea), alkaligrass (Puccinellia distans), and saltgrass (Distichlis spicata), a $50 \%$ shoot growth reduction was observed at 4.9, 10.0, 20.0, and $34.9 \mathrm{dS} \cdot \mathrm{m}^{-1}$ $\mathrm{NaCl}$ treatment, respectively, and a $50 \%$ root growth reduction occurred at 5.8, 19.6, 24.9, and $41.0 \mathrm{dS} \cdot \mathrm{m}^{-1} \mathrm{NaCl}$ treatment, respectively (Alshammary et al., 2004). Photosynthesis is one of the primary physiological processes that is sensitive to salinity (Chaves, 1991; Munns et al., 2006). Salinity may limit photosynthesis through induction of stomatal closure leading to a reduction in intercellular $\mathrm{CO}_{2}$ concentration (Brugnoli and Lauteri, 1991) and inhibition of non-stomatal factors such as chlorophyll synthesis, photosynthetic electron transport reactions, quenching ability of excessive energy through chlorophyll fluorescence (Lee et al., 2004), efficiency of ribulose-1,5-bisphosphate carboxylase/oxygenase for carbon fixation (Delfine et al., 1998; Jaleel et al., 2007; Megdiche et al., 2008), and photophosphorylation (Stoeva and Kaymakanova, 2008).

Turfgrass in many areas is exposed to varying levels of salinity as a result of the increasing use of effluent water. Previous studies have examined various growth and physiological responses to salinity in different turfgrass species and demonstrated that salinity tolerance mechanisms varied in turfgrass species and cultivars (Pessarakli and Touchane, 2006; Qian et al., 2001). Seashore paspalum is one of the most salinity-tolerant turfgrass species and its superior salinity tolerance has been associated with the maintenance of shoot growth rates, osmotic adjustment through the accumulation of proline, glycinebetaine, and inorganic solutes to maintain high tissue water levels (Lee et al., 2004; Marcum et al., 1998; Marcum and Murdoch, 1990, 1994; Peacock and Dudeck, 1985). Salinity tolerance mechanisms in other warm-season grass species such as zoysiagrass (Zoysia japonica) and bermudagrass (Cynodon dactylon) are associated with shoot saline ion exclusion, salt gland excretion efficiency, and leaf salt gland density (Marcum et al., 1998; Marcum and Pessarakli, 2006). Centipedegrass has poor salt tolerance, which has been attributed to the accumulation of high $\mathrm{Na}^{+}$and $\mathrm{Cl}^{-}$levels even at low (100 to $200 \mathrm{~mm}$ ) salinity concentrations (Marcum and Murdoch, 1994). However, little information is available about interspecific variations in photosynthetic responses to salinity stress in turfgrass species despite the importance of photosynthesis in plant stress tolerance. Understanding differential responses of photosynthetic metabolism between turfgrass species differing in salinity tolerance may provide further insights into physiological mechanisms underlying salinity tolerance in turfgrass species. The objective of this study was to examine differential photosynthetic responses of two grasses that vary in tolerance to salinity when they were grown under salinity stress. The two grasses were seashore paspalum, a salt-tolerant grass, and centipedegrass, a salt-sensitive grass.

\section{Materials and Methods}

Plant materials. 'Salam' seashore paspalum and 'Civil' centipedegrass were examined in this study, which were salinit-tolerant and salinity-sensitive cultivars, respectively, based on a previous study (Liu et al., 2009). 
Sods of each species were collected from 3 -year-old field plots in the Turfgrass Experiment Farm at Shanghai Jiao Tong University, Shanghai, China. Grasses were transferred into plastic pots $(17 \mathrm{~cm}$ diameter, $20 \mathrm{~cm}$ height with four holes at the bottom for drainage) filled with $5 \mathrm{~kg}$ sand ( 0.1 to $1.0 \mathrm{~mm}$ diameter) on 20 Apr. 2008. Plants were grown in a greenhouse [with a temperature regime of $30 \pm 5 / 20$ $\pm 5{ }^{\circ} \mathrm{C}$ (day/night), a 12-h photoperiod, $70 \% \pm$ $5 \%$ relative humidity, and with photosynthetically active radiation $(P A R)$ average of 700 $\mu \mathrm{mol} \cdot \mathrm{m}^{-2} \cdot \mathrm{s}^{-1}$ ] for 2 months and then moved into a growth chamber for the experiment. The chambers were set at $30 / 25{ }^{\circ} \mathrm{C}$ (day/night temperature), $75 \%$ of relative humidity, 14 -h photoperiod, and $400 \mu \mathrm{mol} \cdot \mathrm{m}^{-2} \cdot \mathrm{s}^{-1}$ of $P A R$. Plants were fertilized once a week with $40 \mathrm{~mL}$ full-strength Hoagland solution (Hoagland and Arnon, 1950) and mowed twice a week to keep the height at $\approx 10 \mathrm{~cm}$. Plants were watered three times weekly until water drainage occurred at the bottom of the pot at each irrigation.

Salinity stress treatments. Plants were allowed to acclimate to growth chamber conditions for 2 weeks before salinity treatments were imposed. All plants were mowed to the canopy height of $10 \mathrm{~cm}$ before salt stress treatment was imposed to start with a uniform turf canopy. Plants of both species were irrigated with water [control, with electrical conductivity $(\mathrm{EC})=1 \mathrm{dS} \cdot \mathrm{m}^{-1}$ ], $300 \mathrm{~mm} \mathrm{NaCl}$ solution $\left(\mathrm{EC}=26 \mathrm{dS} \cdot \mathrm{m}^{-1}\right)$, and $500 \mathrm{~mm}(\mathrm{EC}=$ $\left.41 \mathrm{dS} \cdot \mathrm{m}^{-1}\right)$ to induce salinity stress for $32 \mathrm{~d}$. These concentrations of salt solution represented moderate to severe salinity stress for the two species based on a previous study (Liu et al., 2009). The salinity level was gradually increased by adding $\mathrm{NaCl}$ solution of 6,12 , and $18 \mathrm{dS} \cdot \mathrm{m}^{-1}$ until the EC of the leachate reached $26 \mathrm{dS} \cdot \mathrm{m}^{-1}$ in the $300-\mathrm{mm}$ treatment and at 10,20 , and $30 \mathrm{dS} \cdot \mathrm{m}^{-1}$ until the EC of the leachate reached $41 \mathrm{dS} \cdot \mathrm{m}^{-1}$ in the 500-mm treatment. The solution with $\mathrm{NaCl}$ was slowly watered into the soil, and care was taken to avoid salt solution on leaves, minimizing potential salt-induced leaf burning. To keep salt concentration constant in the pot during the stress period, distilled water was supplied to compensate the transpiration loss by weighing the pots daily.

Measurement of turf quality, relative water content, and electrolyte leakage. Turf quality, leaf RWC, and EL were measured to compare overall turf performance under salinity stress in two grass species.

Turf quality was visually rated on a scale of 1 to 9 based on the National Turfgrass Evaluation Program guidelines in which 1 represented grasses desiccated with a completely necrotic turf canopy; 9 represented healthy plants with dark green, turgid leaf blades, and a full turf canopy; and 6 represented the minimal acceptable turf quality (Morris and Shearman, 2007).

Leaf RWC was determined according to the method of Barrs and Weatherley (1962) and was based on the following calculation: $\mathrm{RWC}=(\mathrm{FW}-\mathrm{DW}) /(\mathrm{TW}-\mathrm{DW}) \times 100$, where FW is leaf fresh weight, DW is dry weight of leaves after drying at $85^{\circ} \mathrm{C}$ for $3 \mathrm{~d}$, and TW is turgid weight of leaves after soaking in water for $24 \mathrm{~h}$ at $20^{\circ} \mathrm{C}$.

Electrolyte leakage of leaves was measured by the method of Blum and Ebercon (1981) and Marcum et al. (1998) with modifications. Leaves were excised and cut into $2-\mathrm{cm}$ segments. After being rinsed three times with distilled deionized $\mathrm{H}_{2} \mathrm{O}, 0.2 \mathrm{~g}$ leaf segments were placed in a test tube containing $20 \mathrm{~mL}$ distilled deionized $\mathrm{H}_{2} \mathrm{O}$. Test tubes were agitated on a shaker for $\approx 24 \mathrm{~h}$, and the solution conductivity $(\mathrm{C} 1)$ was measured with a conductivity meter (DDS-320; Shanghai Kangyi Co., Ltd., Shanghai, China). Leaf samples then were killed in an autoclave at $100{ }^{\circ} \mathrm{C}$ for 20 min, and the conductivity of the solution containing killed tissue was measured after tubes cooled down to room temperature (C2). The relative EL was calculated as $(\mathrm{C} 1 / \mathrm{C} 2) \times$ 100.

Analysis of photosynthesis and its components. Photosynthetic rate $(\mathrm{Pn})$, stomatal conductance $\left(g_{\mathrm{S}}\right)$, and intracellular $\mathrm{CO}_{2}$ concentration $(\mathrm{Ci})$ were measured in mature leaves using a portable infrared gas analyzer (Li-6400; LICOR, Inc, Lincoln, NE) under a controlled atmosphere $\left(400 \mu \mathrm{mol} \cdot \mathrm{mol}^{-1} \mathrm{CO}_{2}, 500 \mu \mathrm{mol} \cdot \mathrm{s}^{-1}\right.$ flow rate) and a LI-COR 6400 LED external light source [providing a photosynthetic photon flux density $\left.(P P F D)=600 \mu \mathrm{mol} \cdot \mathrm{m}^{-2} \cdot \mathrm{s}^{-1}\right]$. Photosynthetic rate, $g_{\mathrm{S}}$, and $\mathrm{Ci}$ were measured on three samples of leaves in each pot, each sample with five leaves randomly selected.

Chlorophyll was extracted by placing 0.2 $\mathrm{g}$ of fresh leaf tissues in a test tube containing $10 \mathrm{~mL}$ dimethyl sulphoxide and left in the dark for $48 \mathrm{~h}$ (Hiscox and Israelstam, 1979). The absorbance of the resulting solution was measured at 663 and $645 \mathrm{~nm}$ with a spectrophotometer (Helios Alpha, thermospectronic, Rochester, NY) and total chlorophyll concentration was calculated as described by Arnon (1949).

Leaf photochemical efficiency (Fv/Fm) was estimated by measuring the ratio of variable to maximum fluorescence of chlorophyll (Fv/Fm) with a chlorophyll fluorometer (OS1-FL1 OPTI-SCIENCES, Hudson, NH). Measurements were made on intact leaves with the fluorometer after the plants were adapted to darkness for $30 \mathrm{~min}$.

Protein extraction and electropheresis. Total soluble protein was extracted from leaves according to the method of Li et al. (1996) with some modifications. Leaf tissue $(0.5 \mathrm{~g}$ fresh weight) was ground into a fine powder using a mortar and pestle that were pre-chilled in liquid nitrogen. Protein was extracted in $4 \mathrm{~mL}$ of ice-cold phosphate buffer (150 mM, pH 7.0). Solutions were centrifuged twice at $12,000 \mathrm{~g}$ at $4{ }^{\circ} \mathrm{C}$ for $30 \mathrm{~min}$, and the supernatant was collected for protein analysis. Protein content was determined by the method of Bradford (1976). Briefly, $30 \mu \mathrm{L}$ of protein samples was mixed with $3 \mathrm{~mL}$ prepared Bradford solution, which contained $0.01 \%(\mathrm{w} / \mathrm{v})$ Coomassie Brilliant Blue G-250, 4.7\% (w/v) ethanol, and $8.5 \%(\mathrm{w} / \mathrm{v})$ phosphoric acid. The absorbance of the reaction solution was measured on the spectrophotometer (Helios Alpha, thermospec- tronic) at $595 \mathrm{~nm}$ between 5 and $30 \mathrm{~min}$ after reaction. Bovine serum albumin was used to establish a standard curve.

Soluble protein extracts for SDS-PAGE were prepared using the method of Jiang and Huang (2002) with modifications. An equal amount of protein was mixed with SDSPAGE sample buffer [60 mm Tris- $\mathrm{HCl}(\mathrm{pH}$ 6.8 ), 25\% glycerol (v/v), 2\% SDS (w/v), 5\% b-mercaptoethanol (v/v), $0.1 \%$ bromophenol blue $(\mathrm{w} / \mathrm{v})$ ] with a ratio of $4: 1$ (protein sample: SDS-PAGE sample buffer, $\mathrm{v} / \mathrm{v}$ ) and heated at $95{ }^{\circ} \mathrm{C}$ for $5 \mathrm{~min}$. Aliquots of $30-\mu \mathrm{L}$ solutions were loaded on the gel, each lane with $60 \mu \mathrm{g}$ protein. Proteins were separated by discontinuous SDS-PAGE with a Tanon-VE-180 electrophoresis unit (Tanon Oriental, Beijing, China) using a 5\% stacking gel and $15 \%$ running gel. Gels were stained at least $6 \mathrm{~h}$ with Colloidal Coomassie Blue G-250 and destained with deionized water (Neuhoff et al., 1988). The protein band was visualized by optical intensity with Tanon 2500 (Tanon Science and Technology Co., Ltd., Shanghai, China).

Experimental design and statistical analysis. The experiment was a $2 \times 3$ factorial combination (two turfgrass species: seashore paspalum and centipedegrass and three salinity levels: 0,300 , and $500 \mathrm{~mm} \mathrm{NaCl}$ treatment) in a complete block design (one treatment of one species served as the block) with four replications. All data were subjected to analysis of variance (SAS 8.1; SAS Institute Inc., Cary, NC). Treatment means were separated using the least significant difference test at $P=0.05$.

\section{Results}

Physiological responses for salt stress. Turf quality declined with increasing salt concentration and the duration of salinity treatment in both turfgrass species (Fig. 1A). Turf quality of centipedegrass decreased sharply under both 300- and 500-mm treatments. It started to show significant decreases at $12 \mathrm{~d}$ of the $300-\mathrm{mm}$ treatment and $8 \mathrm{~d}$ of the $500-\mathrm{mm}$ treatment. It dropped below the acceptable level at $20 \mathrm{~d}$ of the $300-\mathrm{mm}$ treatment and $16 \mathrm{~d}$ of the $500-\mathrm{mm}$ treatment. Turf quality of seashore paspalum was not significantly affected before $16 \mathrm{~d}$ and was maintained above the acceptable level (6.0) throughout the whole experimental period under the $300-\mathrm{mm}$ treatment. Under the $500-\mathrm{mm}$ treatment, turf quality of seashore paspalum decreased progressively to below the acceptable level after $20 \mathrm{~d}$.

Leaf RWC of centipedegrass decreased significantly below the control level at $8 \mathrm{~d}$ under the $300-\mathrm{mm}$ treatment and to only $73.0 \%$ of the control at the end of treatment (32 d) (Fig. 1B). Under the 500-mm treatment, the decrease was much sharper than that under $300 \mathrm{~mm}$. It declined significantly below the control level at $4 \mathrm{~d}$ and was only $16.0 \%$ of the control at 28 d. Leaf RWC of seashore paspalum decreased to a lesser extent than centipedegrass when compared with their respective controls. Under the 300-mm treatment, RWC of seashore paspalum was not significantly affected 

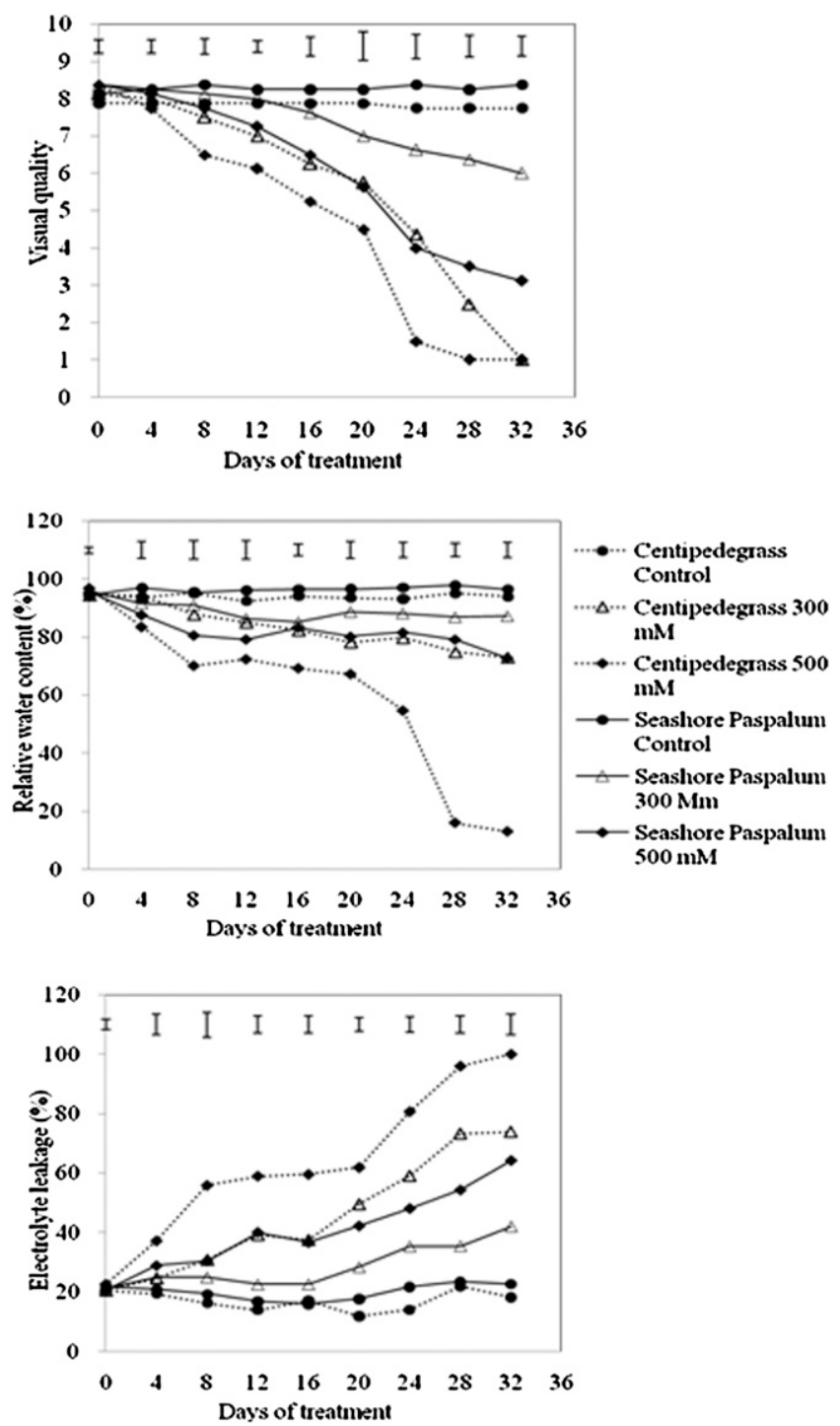

Fig. 1. Effects of salt stress on turf quality, relative water content (RWC), and electrolyte leakage (EL) of seashore paspalum and centipedegrass. Vertical bars indicate least significant difference value $(P=$ $0.05)$.

by salinity until $12 \mathrm{~d}$. Leaf RWC of seashore paspalum was not significantly lower than the control until the end of experiment (at $32 \mathrm{~d}$ ). Under the 500-mM treatment, RWC of seashore paspalum decreased significantly below the control level at $4 \mathrm{~d}$ and to $72.8 \%$ of the control at $32 \mathrm{~d}$.

Leaf EL of centipedegrass increased rapidly with increasing stress duration when grown at $300 \mathrm{~mm}$ and $500 \mathrm{~mm}$ (Fig. 1C). Leaf EL under the 300-mм treatment was significantly higher than the control level beginning at $8 \mathrm{~d}$ and increased to $73.9 \%$ (4.07 times the control) at the end of treatment $(32 \mathrm{~d})$. Under the 500$\mathrm{mm}$ treatment, significant differences in EL between the salinity treatment and the control were observed as early as at $4 \mathrm{~d}$, and the increase in EL was more pronounced than that of 300-mu treatment throughout the whole experimental period. The EL of seashore paspalum was not significantly affected under the 300-mm treatment at 4 and $8 \mathrm{~d}$ but increased rapidly to significantly higher levels than the control thereafter until the end of experiment
(1.85 times the control at $32 \mathrm{~d}$ ). Under the 500$\mathrm{mm}$ treatment, EL increased to significantly higher levels than the control beginning at $4 \mathrm{~d}$. By the end of the treatment ( $32 \mathrm{~d})$, EL under the 500-mu treatment reached 1.82 times the control level.

Photosynthetic gas exchange responses to salt stresses. Net Pn differed significantly among treatments and species (Fig. 2A). The Pn of centipedegrass did not show significant decreases before $8 \mathrm{~d}$ under the $300-\mathrm{mm}$ treatment; however, it decreased sharply from 12 $\mathrm{d}(61.6 \%$ of the control) to the end of treatment (15.1\% of the control). Under the $500-\mathrm{mm}$ treatment, the decreases of Pn started immediately from $4 \mathrm{~d}$ of treatment. The decreases were more severe than that of $300-\mathrm{mm}$ treatment throughout the whole experimental period.

The Pn of seashore paspalum showed significant decreases at 8 and $12 \mathrm{~d}$ under the 300 mu treatment. As salt treatment continued, Pn of seashore paspalum acclimated and showed no significant difference from the control at 16 and $20 \mathrm{~d}$. Afterward, it decreased sharply and remained at levels significantly $(P<0.05)$ lower than the control until the end of the experiment $(58.6 \%$ of the control at $32 \mathrm{~d})$. Under the 500-mm treatment, Pn of seashore paspalum did not show any recovery throughout the whole experiment period. Pn decreased significantly below the control level after $8 \mathrm{~d}$. By the end of the treatment (32 d), Pn at 500 $\mathrm{mm}$ treatment reached $85.3 \%$ of the control.

Stomatal conductance also decreased with the salt stress in both turfgrass species (Fig. 2B). The $g_{\mathrm{s}}$ of centipedegrass did not show significant decreases before $4 \mathrm{~d}$ under the 300 $\mathrm{mm}$ treatment. However, it decreased sharply from $8 \mathrm{~d}(63.6 \%$ of the control) to the end of treatment $(50.5 \%$ of the control). Under the $500-\mathrm{mm}$ treatment, $g_{\mathrm{S}}$ was significantly reduced to below the control level from $4 \mathrm{~d}$. The decreases were more pronounced than that of 300-mm treatment throughout the whole experimental period. The $g_{\mathrm{S}}$ of seashore paspalum showed significant decreases at 4,8 , and $12 \mathrm{~d}$ under the 300-mm treatment. As salt treatment continued, $g_{\mathrm{S}}$ of seashore paspalum recovered and showed no significant difference from the control at $16 \mathrm{~d}$. From $20 \mathrm{~d}, g_{\mathrm{S}}$ of seashore paspalum decreased again and was significantly lower than the control until the end of experiment $(52.1 \%$ of the control at 32 d). Under the 500-mm treatment, $g_{\mathrm{S}}$ of seashore paspalum decreased to a significantly lower level than the control after $4 \mathrm{~d}$. By the end of the treatment ( $32 \mathrm{~d}), g_{\mathrm{S}}$ reached $25.3 \%$ of the control.

Intercellular $\mathrm{CO}_{2}$ concentration $(\mathrm{Ci})$ of centipedegrass did not show significant changes before $12 \mathrm{~d}$ under the 300 -mm treatment; however, it increased sharply from $16 \mathrm{~d}$ (1.06 times the control) to the end of treatment (1.26 times the control at 32d) (Fig. 2C). Under the 500-mM treatment, the increases of $\mathrm{Ci}$ started after $8 \mathrm{~d}$. The increases were more rapid than that of the 300-mm treatment throughout the whole experimental period. The $\mathrm{Ci}$ increased to the maximum $\mathrm{CO}_{2}$ concentration at $28 \mathrm{~d}$ when the plants were completely dead. Under the $300-\mathrm{mm}$ treatment, $\mathrm{Ci}$ of seashore paspalum showed significant decreases at 4 and $8 \mathrm{~d}$. As the salt treatment continued, $\mathrm{Ci}$ of seashore paspalum recovered and showed no significant difference from the control from 12 to $28 \mathrm{~d}$, but $\mathrm{Ci}$ of seashore paspalum was significantly higher than the control at the end of experiment $(1.10$ times the control at $32 \mathrm{~d}$ ). Under the $500-\mathrm{mm}$ treatment, $\mathrm{Ci}$ of seashore paspalum displayed significant decreases at $4 \mathrm{~d}$ compared with both the control and 300-mm treatment, and then $\mathrm{Ci}$ began to increase and showed a significant difference from the control after 12 $\mathrm{d}$ (1.25 times the control at $32 \mathrm{~d})$.

Chlorophyll content and photochemical efficiency. Total chlorophyll content of centipedegrass started to decrease significantly below the control level at 12 and $8 \mathrm{~d}$ under the 300-mm and 500-mm treatments, respectively (Fig. 3A). By the end of the experiment (32 d), chlorophyll content decreased to $23.0 \%$ of the control under the $300-\mathrm{mm}$ treatment and to zero under 500-mm treatment. Leaf chlorophyll content of seashore paspalum did not 

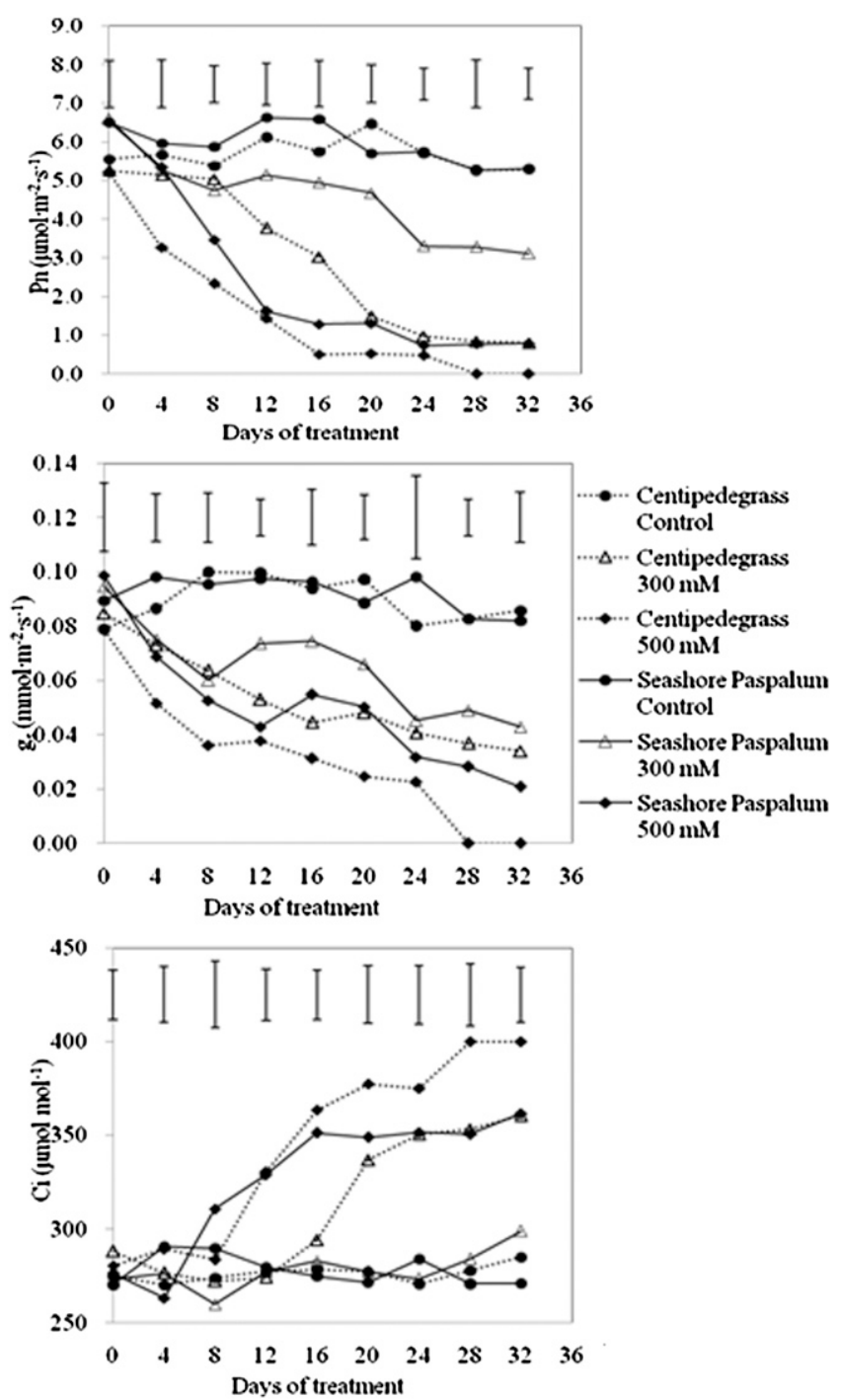

Fig. 2. Effects of salt stress on net photosynthetic rate $(\mathrm{Pn})$, stomatal conductance $\left(g_{\mathrm{S}}\right)$, and intercellular $\mathrm{CO}_{2}$ concentration $(\mathrm{Ci})$ of seashore paspalum and centipedegrass. Vertical bars indicate least significant difference value $(P=0.05)$.

show any significant changes throughout the whole experimental period in both the 300 mu and 500-mm treatments.

Leaf photochemical efficiency of centipedegrass did not show significant decreases until $12 \mathrm{~d}$ under the 300-mm treatment; however, it decreased sharply after $16 \mathrm{~d}$ and reached $64.5 \%$ of the control at the end of the experiment (32 d) (Fig. 3B). Under the 500-mm treatment, $\mathrm{Fv} / \mathrm{Fm}$ decrease was more severe than that of $300-\mathrm{mm}$ treatment throughout the whole experimental period. The $\mathrm{Fv} / \mathrm{Fm}$ did not show significant changes until $28 \mathrm{~d}$ under the 300-mm treatment in seashore paspalum. However, Fv/Fm of seashore paspalum decreased significantly after $8 \mathrm{~d}$ under the 500 mu treatment and reached $90.7 \%$ of the control at the end of the experiment (32 d).

Sodium dodecyl sulfate-polyacrylamide gel electrophoresis for protein changes during salt stress. Leaf protein changes were examined by SDS-PAGE for samples collected at $0,4,8,12,16,20,24,28$, and $32 \mathrm{~d}$ of salinity stress in both turfgrass species. The proteins of $55 \mathrm{kDa}$ exhibited differential responses to different levels of salinity stress between the two grass species (Fig. 4). No significant changes in other proteins were detected between the two grass species.

The band of $55 \mathrm{kDa}$ is a large subunit of Rubisco (Desclos et al., 2008). The SDSPAGE analysis demonstrated that there was no obvious decline in this Rubisco large subunit during the whole stress period under both the $300-\mathrm{mm}$ and $500-\mathrm{mm}$ treatments in seashore paspalum (Fig. 4A). However, there was an obvious decline in the $55-\mathrm{kDa}$ band intensity in centipedegrass (Fig. 4B). The Rubisco large subunit almost disappeared at $20 \mathrm{~d}$ under the $300-\mathrm{mm}$ treatment and $16 \mathrm{~d}$ under the $500-\mathrm{mm}$ treatment.

\section{Discussion}

Plants often suffer from water deficit and ion toxicity when exposed to salinity, resulting in growth inhibition. Relative water content and shoot growth of salt-sensitive turfgrass species are reduced more rapidly than those in the salt-tolerant turfgrasses under salinity stress
(Alshammary et al., 2004; Liu et al., 2009; Suplick-Ploense et al., 2002). In this study, leaf RWC and turf quality showed the earlier and more severe decline, whereas leaf EL showed an earlier and sharper increase in centipedegrass than that in seashore paspalum under both the 300- and 500-mm NaCl treatments. Our results confirmed that seashore paspalum has more salinity tolerance than centipedegrass.

Salinity appears to affect photosynthesis through stomatal closure and damage in the photochemical reactions and carbon assimilation (Megdiche et al., 2008; Stoeva and Kaymakanova, 2008). During initial exposure to salinity, plants often suffer from water deficit as a result of osmotic stress. Stomata close in response to leaf turgor decline, to high vapor pressure deficit in the atmosphere, or to root-generated chemical signals, the latter being common to both drought and salinity. Supply of $\mathrm{CO}_{2}$ to Rubisco is, therefore, impaired and $\mathrm{Pn}$ is decreased. In this study, seashore paspalum showed decreases of $\mathrm{Pn}, g_{\mathrm{S}}$, and $\mathrm{Ci}$ at the beginning of both salinity treatments. However, there were no significant decreases in total chlorophyll content and $\mathrm{Fv} / \mathrm{Fm}$, and these results agree with those of Lee et al. (2004). A small decline in $g_{\mathrm{S}}$ may have protective effects against stress by allowing water-saving and improving plant water use efficiency by the plant (Chaves et al., 2009).

With prolonged salinity stress, $\mathrm{Pn}, g_{\mathrm{S}}$, and $\mathrm{Ci}$ of seashore paspalum showed a recovery period and no significant differences from the control between 16 and $20 \mathrm{~d}$ under the $300-\mathrm{mm} \mathrm{NaCl}$ treatment, suggesting photosynthetic acclimation to a short period. These results indicated that the earlier inhibition of photosynthesis in seashore paspalum was mainly associated with stomatal closure. Light absorption and photochemical inhibition were not the main factors for photosynthesis inhibition during the early period of salinity stress. Similar results were previously reported for bean (Phaseolus vulgaris), cotton (Gossypium hirsutum) (Brugnoli and Lauteri, 1991), sunflower (Helianthus annuus) (Plesnicar et al., 1995), spinach (Spinacia oleracea) (Delfine et al., 1998) and cucumber (Cucumis sativus) (Stepien and Klobus, 2006), and many halophyte species (Huchzermeyer and Koyro, 2005). The photosynthesis decline of spinach leaves when exposed to $1 \%(\mathrm{w} / \mathrm{v}) \mathrm{NaCl}$ was primarily the result of stomatal closure and changes in mesophyll structure, whereas Ribulose-1, 5bisphosphate carboxylase/oxygenase in vitro activity and content and $\mathrm{Fv} / \mathrm{Fm}$ were unaffected up to 20-d exposure to salinity (Delfine et al., 1998). For cucumber, the inhibition of photosynthesis was more the result of stomatal closure than by biochemical activity when exposed to $50 \mathrm{~mm} \mathrm{NaCl}$ for $14 \mathrm{~d}$ and $100 \mathrm{~mm} \mathrm{NaCl}$ for the first $4 \mathrm{~d}$ (Stepien and Klobus, 2006). In some plants such as pepper (Capsicum annuum) (Perera et al., 1994), orange (Citrus sinensis) (Lloyd et al., 1987), and phaseolus bean (Phaseolus vulgaris) (Seeman and Critchley, 1985), the initial reductions in photosynthesis were attributed to non-stomatal factors. It appeared that sensitivity of photosynthetic parameters 

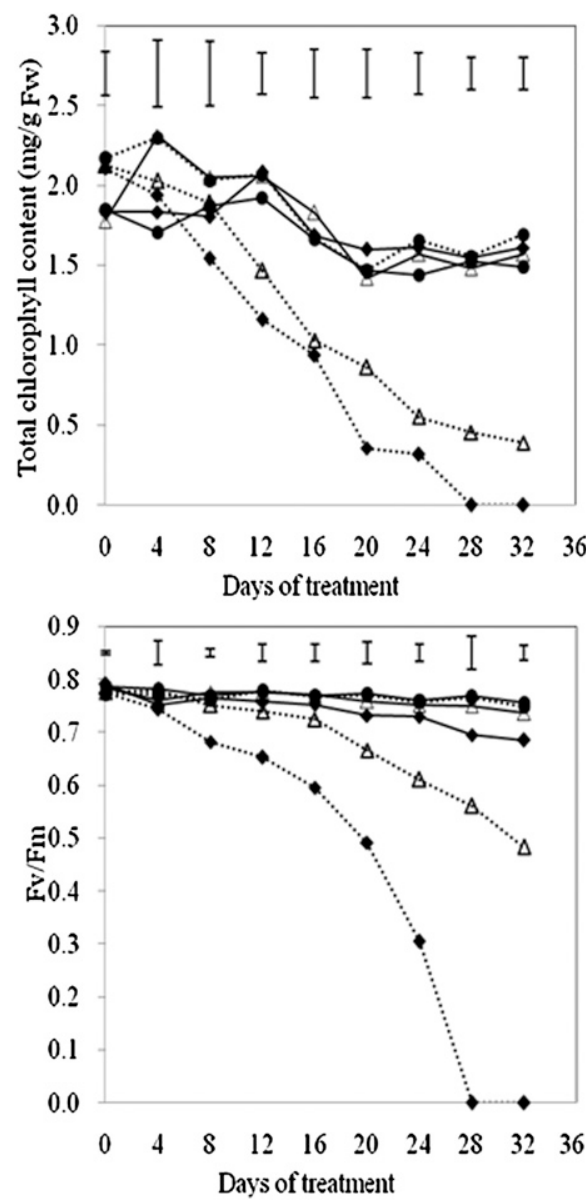

Fig. 3. Effects of salt stress on total chlorophyll content and photochemical efficiency (Fv/Fm) of seashore paspalum and centipedegrass. Vertical bars indicate least significant difference value $(P=0.05)$ for control and salt treatment comparison on a given day.
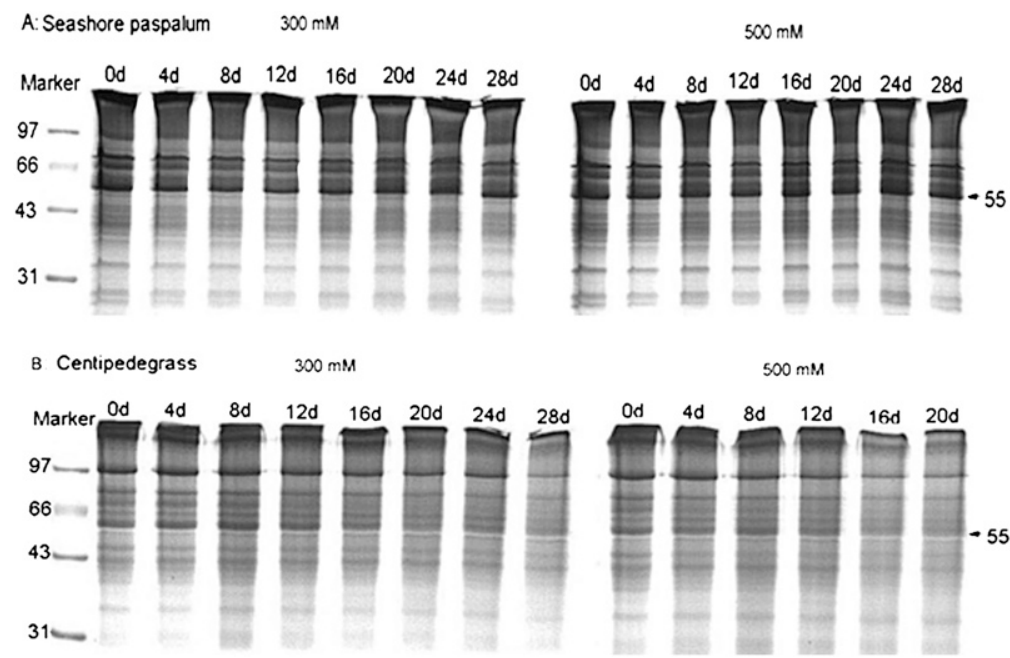

Fig. 4. The sodium dodecyl sulfate-polyacrylamide gel electrophoresis profiles of soluble protein from leaves of seashore paspalum and centipedegrass under salt stress (A: seashore paspalum; B: centipedegrass). Arrows indicate changes of protein in response to salt stress.

to salinity stress or the extent of salinity effects on different photosynthetic components depends on the severity and duration of stress (Lakshmi et al., 1996; Misra et al., 1997) and on plant species (Dubey, 1994).

The Pn of seashore paspalum decreased to below the control again from $24 \mathrm{~d}$ until the end of the treatment. The $g_{\mathrm{S}}$ significantly decreased whereas $\mathrm{Ci}$ significantly increased. Under $500 \mathrm{~mm}$, salinity treatment caused a stronger inhibition effect for seashore paspalum than the 300-mm treatment. These results suggested that either prolonged periods of salinity or a high level of salinity caused photo- synthetic damages, which could be associated with non-stomatal factors such as photosynthetic electron transport, efficiency of photosynthesis enzymes, or photophosphorylation (Sultana et al., 1999).

In centipedegrass, Pn and $g_{\mathrm{S}}$ exhibited continuing decreases, but $\mathrm{Ci}$ continued to increase with duration of salinity stress at both salt concentrations. In addition, significant differences were found in total chlorophyll content and $\mathrm{Fv} / \mathrm{Fm}$ between salinity and control treatments, suggesting that both stomatal closure and non-stomatal factors were responsible for Pn decline in centipedegrass during the whole period of salinity stress at both salinity levels. Similar results were found in rice (Oryza sativa) as reported in Sultana et al. (1999). The reduction in photosynthesis in the salinized rice depended not only on a reduction of available $\mathrm{CO}_{2}$ by stomatal closure, but also on the cumulative effects of leaf water and osmotic potential, $g_{\mathrm{S}}$, transpiration rate, RWC content, and biochemical constituents such as photosynthetic pigments, soluble carbohydrates, and protein.

Salt stress has been shown to alter protein expression and content, and it has been proposed that the activity of key photosynthetic enzyme, Rubisco, is strongly correlated with the decline in photosynthesis during stress conditions (Dionisio-Sese and Tobita 2000; Flexas et al., 2006; Parry et al., 2002). Rubisco is a key enzyme for carbon fixation and assimilation in photosynthesis. The SDS-PAGE analysis indicated that the Rubisco large subunit protein $(55 \mathrm{kDa})$ exhibited more severe degradation in centipedegrass than seashore paspalum with the increasing treatment duration, particularly after $32 \mathrm{~d}$ of the $300-\mathrm{mm}$ $\mathrm{NaCl}$ treatment and $20 \mathrm{~d}$ of the $500-\mathrm{mm} \mathrm{NaCl}$ treatment. These results suggested that seashore paspalum was able to maintain more stable Rubisco proteins for carbon assimilation during severe salinity stress compared with centipedegrass, which may contribute to its superior salt tolerance, as manifested by higher Pn and RWC and lower EL.

In summary, the superior salt tolerance in seashore paspalum to centipedegrass could be attributed to its ability to adjust stomatal opening and the maintenance of high RWC and chlorophyll content and high Fv/Fm. Overall, the rapid closure of stomata during the early period of salt stress may result in water-saving, whereas the maintenance of higher leaf proteins for continued photosynthesis during prolonged periods of salt stress would help seashore paspalum survive long-term salt stress. Further study will be needed to determine the effect of salinity to stomatal closure of seashore paspalum and to determine how to adjust stomatal opening under salt stress.

\section{Literature Cited}

Alshammary, S., Y.L. Qian, and S.J. Wallner. 2004. Growth response of four turfgrasses to salinity. Agr. Water Manage. 66:97-111.

Arnon, D.I. 1949. Copper enzymes in isolated chloroplast, polyphenol oxidase in beta vulgaris. Plant Physiol. 24:1-15. 
Barrs, H.D. and P.E. Weatherley. 1962. A reexamination of the relative turgidity technique for estimating water deficit in leaves. Aust. J. Biol. Sci. 15:413-428.

Blum, A. and A. Ebercon. 1981. Cell membrane stability as a measurement of drought and heat tolerance in wheat. Crop Sci. 21:43-47.

Bradford, M.M. 1976. A rapid and sensitive method for the quantification of microgram quantities protein using the principle of protein-dye binding. Anal. Biochem. 72:248-254.

Brugnoli, E. and M. Lauteri. 1991. Effects of salinity on stomatal conductance, photosynthetic capacity, and carbon isotope discrimination of salt-tolerant (Gossypium hirsutum L.) and salt-sensitive (Phaseolus vulgaris L.) $\mathrm{C}_{3}$ non-halophytes. Plant Physiol. 95:628-635.

Carrow, R.N. and R.R. Duncan. 1998. Salt-affected turfgrass sites: Assessment and management. Chelsea, Ann Arbor, MI. p. 232.

Chaves, M. 1991. Effects of water deficits on carbon assimilation. J. Expt. Bot. 42:1-16.

Chaves, M., J. Flexas, and C. Pinheiro. 2009. Photosynthesis under drought and salt stress: Regulation mechanisms from whole plant to cell. Ann. Bot. (Lond.) 103:551-560.

Delfine, S., A. Alvino, M. Zacchini, and F. Loreto. 1998. Consequences of salt stress on conductance to $\mathrm{CO}_{2}$ diffusion, Rubisco characteristics and anatomy of spinach leaves. Aust. J. Plant Physiol. 25:395-402.

Desclos, M., L. Dubousset, P. Etienne, F.L. Caherec, H. Satoh, J. Bonnefoy, A. Ourry, and J.C. Avice. 2008. A proteomic profiling approach to reveal a novel role of Brassica napus drought $22 \mathrm{kD} /$ water-soluble chlorophyll-binding protein in young leaves during nitrogen remobilization induced by stressful conditions. Plant Physiol. 147:1830-1844.

Dionisio-Sese, M.L. and S. Tobita. 2000. Effects of salinity on sodium content and photosynthetic responses of rice seedlings differing in salt tolerance. J. Plant Physiol. 157:54-58.

Dubey, R.S. 1994. Protein synthesis by plants under stressful conditions, p. 277-299. In: Pessarakli, M. (ed.). Handbook of plant and crop stress. CRC Press. Marcel Dekker, Inc., New York.

Flexas, J., M. Ribas-Carbó, J. Bota, J. Galmés, M. Henkle, S. Martínez-Cañellas, and H. Medrano. 2006. Decreased Rubisco activity during water stress is not induced by decreased relative water content but related to conditions of low stomatal conductance and chloroplast $\mathrm{CO}_{2}$ concentration. New Phytol. 172:73-82.

Hiscox, J.D. and G.F. Israelstam. 1979. A method for the extraction of chlorophyll from leaf tissue without maceration. Can. J. Bot. 52:332-334.

Hoagland, D.R. and D.I. Arnon. 1950. The waterculture method of growing plants without soil. Calif. Agr. Exp. Station Circ. 347:1-32.

Huchzermeyer, B. and H.W. Koyro. 2005. Salt and salt stress effects on photosynthesis, p. 751777. In: Pessarakli, M. (ed.). Handbook of plant and crop stress. 2nd Ed. CRC Press. Marcel Dekker Inc., New York.
Jaleel, C.A., P. Manivannan, and B. Sankar. 2007. Induction of drought stress tolerance by ketoconazole in Catharanthus roseus is mediated by enhanced antioxidant potentials and secondary metabolite accumulation. Colloids Surf. B Biointerfaces 60:201-206.

Jiang, Y. and B. Huang. 2002. Protein alterations in tall fescue in response to drought. Crop Sci. 42:202-207.

Lakshmi, A., S. Ramanjulu, K. Veeranjaneyulu, and C. Sudhakar. 1996. Effect of $\mathrm{NaCl}$ on photosynthesis parameters in two cultivars of mulberry. Photosynthetica 32:285-289.

Lee, G.J., R.N. Carrow, and R.R. Duncan. 2004 Photosynthetic responses of salinity stress of halophytic seashore paspalum ecotypes. Plant Sci. 166:1417-1425.

Li, R., J.J. Volenec, B.C. Joern, and S.M. Cunningham. 1996. Seasonal changes in nonstructural carbohydrates, protein, and macronutrients in roots of alfalfa, red clover, sweetclover, and birdsfoot trefoil. Crop Sci. 36:617-623.

Liu, Y., F. Cheng, Q. Wang, Y. Hu, and Z. Wang. 2009. Salinity stress responses and -thresholds in four warm-season turfgrasses. Acta Prat. Sin. 18:192-199.

Lloyd, J., F.P. Syvertsen, and P.E. Kriedemann. 1987. Salinity effects on leaf water relations and gas exchange of 'Valencia' orange on rootstocks with different salt exclusion characteristics. Aust. J. Plant Physiol. 14:605-617.

Marcum, K.B., S.J. Anderson, and M.C. Engelke. 1998. Salt gland ion secretion: A salinity tolerance mechanism among five zoysia grass species. Crop Sci. 3:806-810.

Marcum, K.B. and C.L. Murdoch. 1990. Growth responses, ion relations, and osmotic adaptations of eleven $\mathrm{C}_{4}$ turfgrasses to salinity. Agron. J. 82:892-896.

Marcum, K.B. and C.L. Murdoch. 1994. Salinity tolerance mechanisms of six $\mathrm{C}_{4}$ turfgrasses. J. Amer. Soc. Hort. Sci. 119:779-784.

Marcum, K.B. and M. Pessarakli. 2006. Salinity tolerance and salt gland excretion efficiency of bermudagrass turf cultivars. Crop Sci. 46: 2571-2574.

Megdiche, W., K. Hessini, F. Gharbi, C.A. Jaleel, R. Ksouri, and C. Abdelly. 2008. Photosynthesis and photosystem-efficiency of two saltadapted halophytic seashore Cakile maritima ecotypes. Photosynthetica 46:410-419.

Misra, A.J., S.M. Sahu, M. Misra, P. Singh, I Meera, N. Das, M. Kar, and P. Shau. 1997. Sodium chloride induced changes in leaf growth, and pigment and protein contents in two rice cultivars. Biol. Plant. 39:257-262.

Morris, K.N. and R.C. Shearman. 2007. NTEP turfgrass evaluation guidelines. 21 July 2008. $<$ http://www.ntep.org/pdf/ratings.pdf $>$. National Turfgrass Evaluation Program, Beltsville, MD

Munns, R. 2005. Genes and salt tolerance: Bringing them together. New Phytol. 167:645-663.

Munns, R., R.A. James, and A. Läuchli. 2006. Approaches to increasing the salt tolerance of wheat and other cereals. J. Expt. Bot. 57:10251043.

Munns, R. and M. Tester. 2008. Mechanisms of salinity tolerance. Annu. Rev. Plant Biol. 59: 651-681.

Neuhoff, V., N. Arold, D. Taube, and W. Ehrhardt. 1988. Improved staining of proteins in polyacrylamide gels including isoelectric focusing gels with clear background at nanogram sensitivity using Coomassie Brilliant Blue G-250 and R-250. Electrophoresis 9:255-262.

Parry, M.A.J., P.J. Andralojc, S. Khan, P.J. Lea, and A.J. Keys. 2002. Rubisco activity: Effects of drought stress. Ann. Bot. (Lond.) 89:833839 .

Peacock, C.H. and A.E. Dudeck. 1985. A comparative study of turfgrass physiological responses to salinity. Intl. Turf. Res. J. 5:821-829.

Perera, L.K.R.R., T.A. Mansfield, and A.J.C. Malloch. 1994. Stomatal responses to sodium ions in Aster tripolium: A new hypothesis to explain salinity regulation in above-ground tissues. Plant Cell Environ. 17:335-340.

Pessarakli, M. and H. Touchane. 2006. Growth responses of bermudagrass and seashore paspalum under various levels of sodium chloride stress. J. Food Agr. Environ. 4:240 243.

Plesnicar, M., Z. Sakac, D. Pankovic, and T. Cupina. 1995. Responses of photosynthesis and carbohydrate accumulation in sunflower leaves to short-term water stress. Helia. 18:2536.

Qian, Y.L., S.J. Wilhelm, and K.B. Marcum. 2001. Comparative responses of two kentucky bluegrass cultivars to salinity stress. Crop Sci. 41: 1895-1900.

Sahar, N.M., H.R. Mehran, H. Manzar, and S.G. Hosseini. 2007. Proteomics reveals new salt responsive proteins associated with rice plasma membrane. Biosci. Biotechnol. Biochem. 71: 2144-2154.

Seeman, J.D. and C. Critchley. 1985. Effects of salt stress on the growth, ion content, stomatal behavior and photosynthetic capacity of a saltsensitive species, Phaseolus vulgaris L. Planta 164:151-162.

Stepien, P. and G. Klobus. 2006. Water relations and photosynthesis in Cucumis sativus L. leaves under salt stress. Biol. Plant. 50:610 616.

Stoeva, N. and M. Kaymakanova. 2008. Effect of salt stress on the growth and photosynthesis rate of bean plants. Agriculture 9:385-392.

Sultana, N., T. Ikeda, and R. Itoh. 1999. Effect of $\mathrm{NaCl}$ salinity on photosynthesis and dry matter accumulation in developing rice grains. Environ. Exp. Bot. 42:211-220.

Suplick-Ploense, M.R., Y.L. Qian, and J.C. Read. 2002. Relative $\mathrm{NaCl}$ tolerance of kentucky bluegrass texas bluegrass and their hybrids. Crop Sci. 42:2025-2030.

Tester, M. and R.J. Davenport. 2003. $\mathrm{Na}^{+}$transport and $\mathrm{Na}^{+}$tolerance in higher plants. Ann. Bot. (Lond.) 91:503-527. 